\title{
Study on the Mode Innovation and Implementation Strategy of English Writing Teaching in Higher Vocational Colleges under the Background of "Internet"
}

\author{
Song Guoping ${ }^{1,}$, , He Yayun ${ }^{1}$ \\ ${ }^{1}$ Kunming Metallurgy College, Yunnan, 650000, China \\ asongguoping@126.com
}

Keywords: Internet; higher vocational English teaching; teaching mode innovation; English writing teaching

\begin{abstract}
The rapid development of Internet technology has brought a new form of teaching. Under the economic situation of "Internet", the traditional classroom-teaching mode can no longer satisfy the students' acquisition of new knowledge resources. The "Internet" teaching mode of English writing teaching in higher vocational colleges can better break the bottleneck of communication in traditional English teaching and bring new vitality to the traditional education. The teaching mode based on Internet is a new exploration direction of modern technical education and a beneficial supplement to traditional classroom teaching. This paper analyzes the present situation of English teaching mode in higher vocational colleges and the teaching mode of English writing based on the Internet through practice. Under the background of Internet, education has gradually merged with network and become an important form of teaching. In terms of higher vocational English education, higher vocational English writing teaching should also actively adapt to the new environment and continue to develop. In view of this, this paper takes the present situation of the teaching of English writing in higher vocational colleges as the starting point and finds out the problems existing in the teaching of English writing in higher vocational colleges from the perspective of educational concepts and educational means.
\end{abstract}

\section{Introduction}

Since Internet technology has penetrated into every aspect of life, writing teaching has also changed smoothly, and various corresponding teaching reforms have come into being. The three thinking angles of "precise thinking, user thinking and experiential thinking" in Internet thinking are closely related to teaching. "Precision thinking" refers to the understanding of students through the analysis of big data, to provide more precise and practical learning content for the students. considering the starting point of English writing teaching in higher vocational education, "user thinking" is to turn teaching-centered into student-centered learning and application to meet the needs of society; "experiential thinking" by setting up a specific for students The learning scene provides a better experience for learning and enables students to improve their learning efficiency in interaction. Education under the background of "Internet" needs the help of the Internet education platform, which aims to realize the above thinking, so that English teaching can make. "Fly" up. English writing is not only an important part of English teaching, but also the most difficult part for students, which makes English writing become a big problem in teaching. How to improve students' English writing ability becomes a primary task for teachers. With the advent of the network age, the Internet is also influencing the teaching mode of English writing. With its advantages of surpassing the limitation of time and space, it enriches the teaching resources of English writing and expands the learning environment of English writing. It promotes the innovation of English writing mode.

\section{The Influence of Internet on English Writing Teaching in Higher Vocational Colleges}

The influence on the change of English Writing teacher's role in higher Vocational Education: Because of the emergence of "Internet", a large number of English writing resources will emerge, 
and students can obtain a large amount of writing materials and related resources through the Internet. Higher vocational English teachers are no longer the only occupants and providers of writing education resources, but should be the guides for students to make good use of the resources. In the face of all kinds of network resources, it is inevitable that students with immature minds will have difficulties in making choices. Making use of the relevant information provided by the network to form its own evaluation, cultivating students' correct learning attitude, learning methods, and the ability to find and solving problems become effective promoters of students' learning, which is the most important of the teachers. In the completely teaching activities, teachers are the initiators of activities, organizers, and instructors, the promotion of learning. The student is the center of the student. Teachers free themselves from the traditional teaching methods, and the teaching process becomes the common experience of teachers and students. The teachers and students, students and students enlighten each other, communicate with each other, and establish equal communication and dialogue. Defining the role of Teachers-first among e-quality in Equality-where the role of teachers.

\subsection{The derailment of English writing teaching and students' practice}

The students in higher vocational schools have weak English foundation, small vocabulary, and unfamiliar grammar and so on. However, teachers in English writing teaching do not consider the students' actual acceptance ability and blindly explain according to the syllabus. The students cannot connect words into sentences or make mistakes frequently in English writing, thus discouraging students' enthusiasm in learning English writing.

\subsection{The monotonous content and form of English writing teaching}

The teaching of English writing in higher vocational schools mostly follows the traditional teaching mode. Teachers write the writing questions on the blackboard or arrange them orally, and use English words to describe the writing situation and let the students write according to the situation. This kind of teaching method is monotonous, lack of vitality, can not fully inspire students, so that students lack of writing ideas and inspiration, can only be forced to write, English writing as a burden.

\subsection{English writing pattern}

In the traditional teaching of English writing, teachers will provide students with two excellent texts in advance to inspire the students ' thinking. But only two of them are far from enough, the students ' contacts are too little , the thinking is restricted, and the written English composition can only be written out simply , so that some English teachers can even organize some universal writing templates . As long as according to the requirements of the writing, the content should appropriately modified, which leads to the formulation of English writing.

\subsection{Lack of practice in English writing}

The environment in which to learn a language is very important. Students and teachers in higher vocational schools use Chinese in their daily communication and use Chinese characters in their daily writing. There is no environment for learning English, so it is difficult to practice the knowledge learned from books. As the saying goes, "good memory is better than bad writing". English writing is not practical, but after all, students will not be impressed, and their English writing level will improved.

\subsection{Lack of timeliness in English writing assignments}

In higher vocational schools, an English teacher will often teach two to three classes, with more students and more homework, and it will take a long time to correct English composition, which leads to the phenomenon that the teacher does not read in detail and the problem feedback is not timely. If this goes on for a long time, the students will lose their enthusiasm for writing and take the lucky mentality of "the teacher won't look carefully" to write, which is not conducive to the improvement of the students' writing level. 


\section{Innovation of English Writing Teaching Mode in Higher Vocational Colleges Based on the Internet}

Internet teaching aims to develop the intellectual resources of the system for education and teaching. With the rapid development of higher education and the change of educational function, the mode of higher vocational education has changed greatly. With information technology, reference service and knowledge service as the basic means, the service and education function, which based on its teaching resources, can not only meet the needs of vocational college students' autonomous learning, but also provide a larger choice space for students' autonomous learning. Of course, the students' English autonomous learning ability has become a necessary condition for the cultivation of innovative ability and quality education. And the purpose of cultivating talents in higher vocational colleges is to train students to develop a certain The ability of in-depth research and independent thinking can provide knowledge according to the different curriculum needs of different majors, according to students' personal professional development goals, future planning and practical skills. As an important way to cultivate the creative ability of students in higher vocational colleges, the autonomous learning ability of English writing in higher vocational colleges, together with the ability of solving problems and thinking innovation, forms the basis of building the students' knowledge and ability system, which is not difficult to see. The training of students' autonomous learning ability in higher vocational colleges coincides with the teaching service function of "Internet" English teaching in higher vocational colleges, which provides a good platform for the cultivation of students' autonomous ability. Large the dynamic teaching content of data analysis is perfect, the resources of "Internet" utilized, and the techniques and methods of mathematical statistics, machine learning and data mining used synthetically to seek students' teaching behavior and learning resources.

\section{The Implementation Strategies of English Writing Teaching Mode in Higher Vocational Colleges Based on the Internet}

In the "Internet" mode, we explore the establishment of an open teaching management mechanism: from the previous relatively closed to open integration. In the flipping classroom, classroom activities mainly include problem determination, independent inquiry, cooperative learning, achievement exchange, feedback evaluation and so on. The main task of classroom activities is to help students accomplish knowledge internalization by organizing students to carry out problem inquiry, cooperative learning and interactive communication. Students who encounter any difficulties in their study can learn from a teacher-student interaction platform such as the World University City space or learn from the BBS community. The forum communicates with students and teachers immediately.

\subsection{The integration of multimedia technology in teaching}

In view of the problems of boring classroom in traditional English writing teaching, it suggested that teachers should combine multimedia technology with classroom. Teachers can search for multimedia materials, such as animation, movies, music, pictures and so on the Internet, edit them into courseware, create an atmosphere for students in class and make students experience themselves. For example, when writing a composition on such topics as gratitude, you can play some related videos of Thanksgiving parents, teachers, and so on, so that students can get double feelings through vision and hearing, which will resonate with students and enlighten students' thinking. At the same time to provide students with writing materials, so that students have content to write.

\subsection{Make use of the network to create a learning atmosphere}

The Internet makes the world a global village, and Chinese children can become friends with foreign children. Teachers can make use of this to encourage students to communicate with people in English-speaking countries by mail. While writing emails, they can exercise students' writing 
ability and strengthen the application of students' vocabulary and grammar. Let students have a real learning atmosphere, experience the fun of English writing, and cultivate their writing ability.

\subsection{Rationally apply communication tools}

In the Internet age, the exchange and connection between people breaks through the limitation of time and space, and the most extensive communication tool is micro - letter and QQ. In the teaching of English writing, higher vocational teachers can make reasonable use of these convenient and quick communication tools, such as building a micro - letter group with the students, and sending the excellent English writing model to the group for reference;

When the student is English composition approved, the student can contact the student in time, correct the errors in time, and improve the efficiency;

Students can also ask teachers at any time to send the problems encountered in English writing to teachers in the form of words, pictures or videos, and teachers should be in time. Carry out targeted guidance; really achieve the teaching according to their aptitude.

\subsection{Encourage students to learn actively through the Internet}

Now there are all kinds of English learning Apps on mobile phones, teachers can encourage students to download some English learning Apps to help improve their English writing ability. For example, you can download the App-memorize of English words, recite cards every day, increase students' vocabulary and use more vocabulary when writing in English. You can also download a special grammar app; which students cannot understand in class. Can solved through App, rhythm by their grasp, Students use the network to learn more actively than to force to learn by teachers the effect of learning is better, writing ability will improve faster.

\section{Summary}

"Internet plus" era, enhance the diversity of teaching mode, has gradually changed the teacher role in teaching, to improve students' learning initiative. The teacher by making full use of large data network platform, accurate assessment of the students, do the plan and measures of promotion greatly improve the effect of English writing teaching in higher vocational colleges. In a word, the continuous development of the Internet has provided more ways and means for the teaching of English writing, which has enriched the teaching of English writing. English teachers in higher vocational colleges should follow the trend of the times, introduce the network into the classroom, the teaching mode of English writing, and improve and develop the students' English writing level in higher vocational colleges.

\section{References}

[1] Li Y y, Ma S xi, Huang R h. learning analysis technology: service learning process design and optimization [J]. Research on Open Education 5: 18.

[2] G X q, Zhang J l, C H Y. Learning Analysis: emerging data Technology [J]. Distance education magazine 1: 18-25 in 2012.

[3] Yu W S. Experience teaching mode and the writing thought and characteristics of College experience English [J]. The Chinese foreign language is 7: 43-49 in 2005.

[4] Huang X li. A probe into the Model of Autonomous College English Learning [J]. Journal of Fooling normal University.

[5] Z X 1, Song, quant, Jiao Li Zhen. Teaching design based on the concept of turning classroom in information environment, JUJU. Open Education Research, 2013 (1): 58 - 64.

[6] Davies R S, Dean D L, Ball N. Flipping the classroom and instructional technology integration in a college-level informal-ton systems spreadsheet course [J]. Educational Technology $\mathrm{Re}-$ search and Development, 2013 (4): 563-580. 
[7] Q X y, Yan H y. A study on the Teaching Reform of College English Writing against the background of the Internet [J]. Teach and educate people (higher Education Forum, 2007 / 7).

[8] Wang G q. A Probe into the Teaching Model of College English Writing under the Network Environment; Journal of Nanchang Institute of Education, 2010 (4).

[9] Ye Chang. Exploration and practice of Project Teaching of English Writing in higher Vocational Colleges under the Mode of Internet [J]. Intelligence! 17! 1! 90 